Journal of Humanities and Social Sciences Studies (JHSSS)

ISSN: 2663-7197

DOI: 10.32996/jhsss

Journal Homepage: www.al-kindipublisher.com/index.php/jhsss

\title{
Cultural Preservation of Panay Bukidnon-Halawodnons Amidst Emergent Society
}

\author{
Elias C. Olapane, PhD ${ }^{1} \square$ Lalaine E. Ricardo ${ }^{2}$ and Jenewel M. Azuelo ${ }^{3}$ \\ ${ }^{1}$ West Visayas State University Calinog Campus, Calinog, Iloilo, Philippines \\ ${ }^{2}$ Capiz State University-Mambusao Satellite College, Mambusao, Capiz, Philippines \\ ${ }^{3}$ Ajuy National High School, Ajuy, Iloilo, Philippines
}

$\square$ Corresponding Author: Elias C. Olapane, E-mail: elias.olapane@wvsu.edu.ph

\section{ARTICLE INFORMATION ABSTRACT}

Received: 08 October 2021

Accepted: 14 November 2021

Published: 19 November 2021

DOI: 10.32996/jhsss.2021.3.11.4

\section{KEYWORDS}

Iloilo, Philippines, Cultural

Preservation, Emergent Society, Ethnography, Panay, BukidnonHalawodnon.
Ethnic groups are known as minorities in any society. However, the richness of their culture can never be undermined, rather, it serves as defining stuff of history that is worthy of being upheld and preserved. This ethnographic study was specifically designed to investigate how the Panay Bukidnon-Halawodnons in barangay Agcalaga, Calinog, Iloilo, Philippines upheld their cultural society amidst the influence of the mainstream institutions in their community during the $1^{\text {st }}$ quarter of 2019 . The informants were chosen through purposive sampling on the basis of the inclusion criteria set before them. Permission from the National Commission on Indigenous Peoples (NCIP) and the cultural community was secured prior to the conduct of fieldwork in the said area. The researchers performed data triangulation and ground truths for the validity of data and observed data saturation for the reliability of the gathered data. NVivo 12 Plus was used for conceptual analysis while the researchers themselves did the analytic analysis. Barangay Agcalaga is generally on its midway progress. Being a cultural community, the Panay Bukidnon-Halawodnons in this place maintain their cultures such as Council of Elders, "binanog" dance, rituals in farming, house construction, circumcision, dagaan, luy-a luy- $a$, and batak-dungan; bayanihan; babaylan; and love of nature while their lost cultures include binukot; serenade (harana); traditional IP house; burial rites (embalming); dowry system; primitive costumes (bahag and patadyong). The Philippine government is called to ratify the Indigenous and Tribal Peoples Convention No. 169 or Convention 169 to fortify the cultures of the Indigenous Peoples not only in Calinog, Iloilo but also in the entire country.

\section{Introduction}

Indigenous Peoples (IPs) are part and parcel of any society. Their existence truly signifies that the government, in one way or another, cares for them. Apparently, there are hundreds of recognized cultural communities in the Philippines and one of them is the Panay Bukidnon. This cultural community is known as culture bearers of the Sugidanon epic, "binanog dance", "panubok "embroidery, and the practice of "binukot" (kept maiden) (Muyco, 2016; Gowey, 2014).

Members of Panay Bukidnon are mostly scattered in the mountainous hinterlands of Central Panay, especially along the boundaries of Iloilo, Capiz, Aklan, and Antique (Gowey, 2014; Asong \& Seraspe, 2002). Even though this cultural community has one identity, they are called differently based on the river that these provinces have. In Iloilo, Panay Bukidnons are called Halawodnons and most of them are located in the municipality of Calinog. Based on the record of Calinog Tourism Office (2018), barangay Agcalaga belongs to the top 5 with the most number of IP members in the town and is known as members of Garangan-Masaroy-Agcalaga Certificate of Ancestral Domain Title (GMA-CADT).

Copyright: (C) 2021 the Author(s). This article is an open access article distributed under the terms and conditions of the Creative Commons Attribution (CC-BY) 4.0 license (https://creativecommons.org/licenses/by/4.0/). Published by Al-Kindi Centre for Research and Development, London, United Kingdom. 
These Panay Bukidnon-Halawodnons have existed even prior to the coming of the Spaniards in the country and are governed by its political and social organization. Not until 1991 when the Local Government Code was institutionalized which required the establishment of barangays in each town and governed by Barangay Chairman/Captain (Marcos, 2014; Talledo, 2004). Such law has brought considerable impact on the political and social sphere of these IP communities in most barangays in Calinog, particularly those who are located near the town, like barangay Agcalaga which has become more susceptible to lowland influences brought about by sudden modernization endeavors. More so in this place, because the Jalaur River Multi-Purpose Project (JRMP) Phase 2 is underway in the said barangay. JRMP is considered the largest dam outside Metro Manila, the capital of the Philippines. These developments in Agcalaga captured the interest of the researchers to conduct a study in order to explore how Panay Bukidnons in barangay Agcalaga, Calinog, lloilo uphold their culture amidst the emergence of institutions in their community in the $1^{\text {st }}$ quarter of 2019.

This study further intended to investigate whether the community can still be considered indigenous and/or acculturated into the larger mainstream of Philippine society.

\section{Literature Review}

\subsection{The History of Panay Bukidnons-Halawodnon of Calinog, Iloilo}

Due to the absence of recorded history $\mathrm{H}$. Otley Beyer who suggested the "wave theory" of migration - a series of arrivals in the archipelago bringing in different types and levels of culture. There are three waves associated with this: the Negritos, the Indonesia $A$ and $B$, and the Malay. The seco, the existence of natives in the Philippines can be viewed using two (2) schools of thought. One view is linked to Professor nd view of the "wave theory" was postulated by Robert Fox, F. Landa Jocano, Alfredo Evangelista, and Jesus Peralta who maintain that the Negritos, Indonesians, and Malays stand co-equal as ethnic groups without anyone being dominant, racially or culturally, and the random and unstructured advent of these groups (Gamosa, 2014).

Here in Panay Island, its topography gives rise to an assumption that most of the hinterlands of Panay may have been uninhabited prior to the coming of the Spaniards. The Bukidnons are fair-skinned original inhabitants of such island though they have been assimilated in varying degrees with mainstream Visayan society. They are locally named according to the name of the main river system, on the upstream regions thereof, they dwell; "Halawodnon" in Iloilo after the ancient name of Jalaur River (Halawod); "Panayanon" in Capiz after Pan-ay River; "Akeanon" in Aklan after Akean (Aklan) River. They are famous for their very rich oral traditions, their "Binanog" (meaning 'way of the hawks'), and the recently discovered unabridged version of the 'Hinalawod' epic (NCIP, 2018).

There is no doubt since the provinces of Iloilo and Capiz were already inhabited by Atis/Malayan stock Panay residents before Spaniards came which made them easy to establish pueblos and building through conscripted labor the still surviving old churches of the towns of Passi (now a city), Dueñas, and Calinog, lloilo, as well as Dumalag, Capiz, something which the first colonizers could not have done if these places were not amply inhabited (Gamosa, 2014).

It has been postulated that the colonization distorted the ethnic landscape of Panay, including Iloilo - the more docile Malayan settlements readily embraced Christianity and the vestiges of colonialism, while those who refused moved inward. Thus, there is the belief that most of today's Panay Bukidnons are the descendants of the Malayan coastal settlements who moved to the hinterlands of Panay by moving upstream the navigable rivers of Panay - Akean/Aklan River in Aklan (who became the Akenons); Pan-ay River in Capiz (who became the Panayanons); and Halawod/Jalaur River in Iloilo (who became the Halawudnons), with the late Dr. Jocano reinforcing this new (Gamosa, 2014).

It is postulated that there were already sizeable human populations in the area at least shortly before the Spaniards came in the 18th century, or even long before that because the Humadapnon setting recounted in the Hinilawod could have derived inspiration from events and time much earlier. The Bukidnons of Calinog, Iloilo are the descendants of the Malay communities of the area who moved up to the hinterlands to defy Spanish attempts to subjugate them, or they are in fact natives of the place long before the coming of the Spaniards, the same conclusion should emanate - they are indigenous. The ancestors of these people obviously remained to live as recognized communities free of Spanish influence all throughout the Spanish colonial rule as shown by, among others, the dearth of Catholic believers in the area to this day, which is usually proof of an effective Spanish subjugation (Gamosa, 2014). In addition, the upland Calinog was one of the impregnable anti-Japanese guerilla bases during World War II.

\subsection{History of Bukidnons in Calinog, Iloilo}

The Panay Bukidnon people were previously called "Sulod" by their neighbors because of the sandwich-like location of their territory, which literally means closet or room. However, because of the socially unfavorable connotation which the Christian lowlanders attach to the term Sulod - who take it to mean untamed or wild - many of the mountain people resent being called by this name. The term Panay Bukidnon was more recently coined by Dr. Alicia P. Magos, a former UP Visayas professor who's spent over 25 years documenting the Sugidanon epic, and which literally translates to People of Panay (Haliya, 2017). The addition of 
"Panay" distinguishes the Panay Bukidnon from the Bukidnon people of Mindanao, Negros, and other nearby islands (Gowey, 2016).

Dr. Jocano postulated that the Panay Bukidnons (his "Sulod society") was once coastal dwellers. Dr. Alicia P. Magos, a student of Dr. Jocano herself, and retired as a resident anthropologist of the University of the Philippines in the Visayas, took over and conducted decades of research on the PanayBukidnons. She had long theorized that they have dwelled in the area as far back as the 21st Century or even earlier (Gamosa, 2014).

Panay Bukidnons are rich in oral traditions - unwritten prose and poetry, are still sung/chanted, e.g., ambahan, sugidanon,dilot, ulawhay, handed down from generation to generation. They still have their distinctly indigenous dance - the Binanog (Kinaray-a, meaning "way of the hawks/like the hawks"), the courtship dance of the Panay Bukidnons. On special occasions, they, especially the women wear colorful ingenuous costumes/personal adornments (Gamosa, 2014).

The greatest cultural achievement of the Panay Bukidnons is their sugidanon or epic, Hinilawod (means "Tales of the Halawod River"). It recounts the exploits of three demigod brothers, Labaw Donggon, Humadapnon, and Dumalapdap, of ancient Panay. Originally committed to memory and orally handed down through the generations, especially by the Binukots ("Well-kept Maidens") of the Bukidnons communities, when fully documented in the late 1990s by Dr. Magos and her team of academics from UP in the Visayas, it consists of twelve (12) encyclopedic volumes. It has 28,000 plus verses, in Ligbok, an archaic form of Kinaraya. When continuously chanted in its original form without any break, it would take about three (3) days of continuous recitation (around two (2) months in its usual serialized presentation), making it one of the longest epic known, alongside that of India's Mahabharata and Tibet's Epix of King Gesar. Hinilawod is not just a literary piece, but also a source of information about the culture, religion, and rituals of the ancient people of Panay. Its themes center on the importance of family honor and personal courage and dignity (Gamosa, 2014).

The only known living persons who can recite the epic entirely are Mr. Federico 'Tay Pedring' Caballero, one of the three (3) recipients of the 2001 Gawad Manlilikha ng Bayan (GAMABA) Award, along with his younger brother Mr. Romulo 'Tay Mulok' Caballero, recipient of 2004 'Search for Outstanding Indigenous Leaders' (SOIL) Award for Culture, of the Garangan, Calinog Community (also claimed by Tapaz, Capiz) (Gamosa, 2014).

At present, the history of Calinog Bukidnons is characterized as a struggle to obtain security of tenure and autonomy within their ancestral domains - a struggle that has been long and bloody. Government neglect and gradual dispossession of their lands by unscrupulous lowlanders transformed the anti-Japanese movement into a Communist insurgency, both under the old Hukbong Mapagpalaya ng Bayan (HMB) or Huks and the New People's Army (NPA) from the 1950s to early 1990s, with the active or tacit support of some Bukidnons (Gamosa, 2014). Clearly, the issue of land tenure of the Bukidnons had become a cause of discontent and a sense of oppression, leading to armed rebellion. It is thus not surprising that many prominent NPA members came from the upland barangays of Calinog (Gamosa, 2014).

The proclamation of about ten thousand $(10,00)$ hectares of upland Calinog into the Jalaur Watershed and Forest Reserve in 1990 was unknown to the Bukidnons until the Department of Environment and Natural Resources (DENR) implemented massive reforestation projects starting that year. Restriction of farming activities if not forced relocation of communities intensified and a number of Bukidnons were arrested, prosecuted, and convicted for violation of forestry laws (Gamosa, 2014).

However, the Bukidnon people all over Panay Island have not been fully accounted for as not all barangays have been surveyed due to their far interior location. Many of them have also intermarried with non-Bukidnon and have settled on the coast (Magos, n.d.).

\subsection{Socio-Political Organization of Panay Bukidnon in Calinog, Iloilo}

Before its integration into the Philippine government structure, the Panay Bukidnon has some kind of social organization. They have close family ties, in short clannish. The families of siblings, cousins, and other blood relatives form a Clan (Kaliwatan) (Gamosa, 2014).

The clan is led by a Magurang (Elder), not necessarily the oldest male member and regardless of economic status. He or she is the most senior in the hierarchy of the decision-making process in the clan and the clan's representative in the traditional Konseho kang mga Magurang (Council of Elders) of the community. The male elder is also called Amang or Tatay/Tay (meaning, 'Father') or Lolo (meaning, 'Grandfather') if the man is already quite advanced in age at least 60 years old. In some communities, the male Magurang may also be called Agtay, the female Magurang as Inay. If the Magurang is already advanced in age (at least 70 years old), he or she is preferentially known as Mal-am or Agurang (meaning, 'old man/old woman). Among the Magurangs, Mal-am occupies higher standing or respect in society. They are considered the 'culture bearer,' 'Historian,' or 'Living Archive,' as he or she is the repository of the community's oral history, culture, and traditions (Gamosa, 2014). 
It is generally patriarchal. In the household, the father or husband is the head of the family/household and decides for and on behalf of the family. The wife, on the other hand, becomes the head of the family/household in case the husband dies, long absence, or permanent incapacity. Among siblings, the oldest male takes over leadership of the family in case of the death, long absence, or permanent incapacity of both parents. If all the siblings are females, the oldest is usually, but not necessarily, on top of the hierarchy, and the order of succession follows from the eldest to the youngest (Gamosa, 2014).

As a consequence, the traditional council of Elders/Leaders are predominantly composed of males. A female becomes a Magurang usually in substitution of her husband who was such, in case of his death, long absence, or permanent incapacity, and there is no qualified male next-in-line to her late husband as the clan's Magurang. However, this is rarely happened due to their customs (Gamosa, 2014).

The Council of Elders/Leaders during the older times was led by a head man, village chief, or overall leader chosen at large by the community, and not just by the Council of Elders. He or she is usually the elder/leader who has shown or demonstrated the highest wisdom and who commands the highest respect of the members of the community, especially the younger generations. Pinakatarahaon is usually the elder who possesses the highest wisdom and who commands the most respect of the members of the community, especially the younger generations. Emphasis on the ability to command the respect of the younger generations is generally understood to be born out of the need for continuity of the traditions and customary laws of the community. The spouse of the Pinakatarahaon is usually accorded the same respect as his/her spouse, but he or she is or not allowed to wield the authority of his/her spouse in the latter's absence or unavailability, authority being considered vested in the person of the Pinakatarahaon only (Gamosa, 2014).

In 2008, the Sangguniang Bayan of Calinog passed a resolution declaring the 29th month of October as Indigenous People's day in their town. This is to recognize the living culture of the Panay Bukidnon 'Suludnon', particularly the respect and preservation of their identity. At present, some 30-hectares of land on the mountainous village of Calinog are now being protected and inhabited by the Suludnon (Basco, 2008). Besides, Sen. Loren Legarda underscored that sustainability of cultural preservation is a collaborative effort between private and public sectors, including the National Commission for Culture and the Arts (NCCA), the National Commission on Indigenous Peoples (NCIP), the local government units (LGUs), the non-government organizations (NGOs), and the academe (Gamosa, 2014).

At present, Barangay Agcalaga is experiencing weakening, if not outright disappearance, of the traditional position of the Pinakatarahaon, an overall community leader who not only leads the traditional Council of Elders/Leaders but also the community at large, becomes a telling factor in the fragmentation of the community, but also of the non-IPs as well. Without a single visible leader, the collegial relations between and among the Magurangs are also weakened if not already broken or have altogether disappeared. Members of the community who long for strong community leadership begin gravitating towards the non-traditional leadership of the Punong Barangay who leads the Sangguniang Barangay because, in the case of Agcalaga, their traditional Pinakatarahaon now occupies a weakened position(such a traditional leader may thus be termed a "weak" Pinakatarahaon in the sense that he/she no longer commands the respect of the members of the community at large), or in the case of Cahigon, they no longer have a traditional Pinakatarahaon at all. Meanwhile, while the Punong Barangay may also be an IP and has been popularly elected, he/she does not qualify as the traditional Pinakatarahaon and is reduced to the role of a plain Chief Executive of the community as LGU. He/She is not in the category of the Punong Barangay-Pinakatarahaon in semi-open communities who is both the traditional and non-traditional overall leader of the community, respected and obeyed by both the traditional Council of Elders/Leaders and the Barangay political organization, and the members of the community at large" (Gamosa, 2014).

In the long-term, it is hoped that a strong Pinakatarahaon gets to be selected by the community: one who is not only the overall leader of the IPs but also that of the entire barangay, the non-IPs included, as can be shown by his/her also getting to be elected as the Punong Barangay. Subsequently, if the IPs' Pinakatarahaon gets to be habitually elected as Punong Barangay, the IPs may rely on their own resolve to recognize the Punong Barangay elected from their ranks to also act as their traditional Pinakatarahaon during the period of his/her incumbency in the same manner as that prevailing in the semi-open communities. The IPs may select a traditional Pinakatarahaon separate and distinct from the Punong Barangay only if the incumbent Punong Barangay of Agcalaga is a non-IP (Gamosa, 2014).

Being classified as an open community, barangay Agcalaga has already been weakened or may have altogether disappeared. The incumbent Punong Barangay has become the most influential person in the community. The center of gravity of decision-making for the community is already on the Sangguniang Barangay, over which the traditional council of the Magurangsno longer has ascendancy. The Magurangs have been relegated to an advisory capacity, if at all (Gamosa, 2014).

The Magurangs may no longer have regular meetings (sinapul). And may convene only if they are to act or decide on ancestral domain concerns, which cover only a portion of the barangay (Gamosa, 2014). 
However, there is a dichotomy in the decision-making processes. If the matter or issue is purely that of the barangay as an LGU, it is the Sangguniang Barangay which decides, but the IPs also participate as residents of the barangay; if it relates to the ancestral domain, it is the Council of Elders/Leaders which decides, and only the rights holders who participate (Gamosa, 2014).

The traditional consensus-building and decision-making process are still there in the community, as important matters are acted or decided also in a community general assembly (pagtiriripon). As much as possible, they also endeavor to come up with a consensus (paghirisugot). But if no consensus can be reached, they immediately decide the matters by voting on it, with the will of the simple majority prevailing. However, this refers to matters which are simple. They have not yet encountered the situation where they have to approve or disapprove a program project or activity which would result in dislocation and displacement of some if not all of the members of the community (Gamosa, 2014).

Capacity to act. A member of the community comes of age and thus becomes capacitated to act his/her own moment he/she reaches the age of eighteen (18). The community has thus adopted the same threshold as that of mainstream Filipino society (Gamosa, 2014).

Capacity to contract marriage. In the past, a woman is considered of marriable age the moment she reaches the age of puberty, while a man must be of age, and not just at least the age of eighteen (18), but out of teenage years, and so generally at least twenty-one (21). This is because the man must be able to support not just himself, but also his wife as well as their children. The marriage of a woman still in her teens must have the consent of her parents and guardians. Traditionally, they have a dowry system whereby the man or his family must pay a bride price a certain amount or give valuable personal or real property to the family of the woman. Curiously, in recent memory, these communities have no instances of pre-arranged marriages, although marriage between cousins is common, resulting in interlocking families (Gamosa, 2014).

Indigenous marriage customs and practices. The consent of the family of the prospective bride is obtained through a pamalaye, whereby the family of the prospective groom visits the family of the former. If the parties agree to marry, the families of both parties give their consent to the marriage (paghirisugot). Henceforth, the parties may begin to engage in a trial marriage (hungaw), whereby the man comes to live with the family of his bride and renders services to her family (panerbehan). This period usually lasts for at least six (6) months, whereby the contracting parties find out for themselves if they are compatible. After the expiration of the said period, if the trial marriage is unsuccessful, either of the parties may resume their status as unmarried individuals. But if the trial marriage is successful, the contracting parties and their families sponsor a feast and invite the Council of Elders/Leaders and members of the community where the bride resides to attend, whereby the Elders/Leaders declare the existence of a marriage bond (himpit) between the contracting parties and recognize them as a couple. Thus, there is no single person who is authorized to solemnize a traditional marriage between members of a Panay Bukidnon community, because it is solemnized by the Council of Elders/Leaders as a collective function. The marriage ceremony is the himpitrather than the Paghirisugot or the hungaw (Gamosa, 2014).

Multiple marriages. Traditionally, polygamy (multiple marriages by a man) is practiced and allowed, provided that two requisites are complied with: (1) the man is able and willing to provide for the needs of the second wife and children with her if any; and (2) the taking of the second wife is with the express or implied consent of the first wife. The second wife is called the dapli (literally, meaning "viand") (Gamosa, 2014).

However, as early as the 1950 's, the community decided on its own to discourage if not abandon the practice, citing the need to conform also with the mores of the larger Philippine Christian society whioch frowns upon, or even outlaws the practice. ("Nakita man namon ang pagkakinahanglan nga kami mangin sibilisado man sa kara nga aspeto.")

Concept of civil indemnity for intentional homicide and physical injuries. Panay Bukidnons have the concept of traditional civil indemnity for intentional homicide (bugay/bugay-bugay)and physical injuries (hirugo). This may constitute payment of money, and/or the rendering of services by the culprit to the family of the victim, usually the clearing for a new kaingin (swidden farm) in case of intentional homicide, or the giving of valuable material things (usually bangkaw[spear]), in case of homicide physical injuries, as agreed upon by the parties before the Manoghusay. Full settlement of the obligation is deemed closure of the matter, and a bar for the aggrieved party to seek revenge or criminal prosecution against the culprit. Where a criminal case has been filed before the civil authorities, the aggrieved party must desist from pursuing the case, and witnesses to the incident who are members of the community must not testify when subpoenaed to do so (Gamosa, 2014).

Concept of civil indemnity for damage to property. The community still practices kaingin, their traditional and customary mode of swidden farming/agriculture. Employing slash and burn techniques, there can be instances when the swidden farmer through lack of foresight or skill, would unintentionally cause damage to property. The civil indemnity for such damage to burial grounds 
due to an uncontrolled grass fire is called "hinangyas". The culprit must pay the family/families of the dead interred in the burial ground an amount equivalent to the expenses incurred for the burial of the dead relative(s) (Gamosa, 2014).

\subsection{Salient Points of Indigenous People's Rights Act}

The Republic of the Philippines recognizes the right of indigenous people to practice their culture within the parameters of the constitution. In 1997, the Philippine Congress enacted Republic Act 8371, known as the Indigenous Peoples' Rights Act to protect the welfare of indigenous peoples (La Viña, 2015).

The law allows the indigenous people to practice their culture and encourages them to practice their commonly accepted dispute settlement practices provided that these are in accord with existing laws of the Philippines. This policy also helps reduce the voluminous cases that are still undecided by the regular courts (Rio, 2016).

The National Commission on Indigenous People (NCIP) is an agency of the government that is tasked to formulate and implement programs and policies for the indigenous people. Because of the high rate of illiteracy among the indigenous people, the agency is primarily concerned with protecting indigenous peoples' ancestral domains, their beliefs, customs, and traditions.

The NCIP has evolved through a series of government reorganizations in an effort to properly address the multifarious issues and concerns confronting the country's diverse indigenous cultural communities, and to effectively, efficiently, and responsively deliver basic services to them (Rio, 2016).

With the implementation of the Local Government Code, some magurangs as cited in (Rio, 2016) told that "all cases, violent or not, are under the scope of indigenous dispute settlement, from wife-beating to massacre". The law specifically authorizes indigenous cultural communities to settle village disputes through the indigenous mechanism. This is not only legal but practical due to the multi-ethnic nature of the Philippines (Rio, 2016).

Vengeance is encouraged in Panay Bukidnon culture. The value of a person is expressed in a person's ability to keep his honor in the community (Brandon and Richard 1999, in Rio, 2016). According to many magurangs "if you have no honor, your value as a person is lower than the price of a tobacco leaf and to avenge the loss of a clan member is to keep the value of one's honor intact and beyond question". Vengeance has a very important role in the justice system in the Panay Bukidnon culture. For them, vengeance sustains morality and serves as a control mechanism to regulate human conduct and strengthen social order in the community (Rio, 2016).

In many cases, the indigenous customary laws may contradict the western frame of justice, which is punitive in nature and highly compartmentalized. In the Panay Bukidnon culture, being old implies possessing qualities such as experience and wisdom, which are necessary for deliberating community concerns including dispute settlement. However, not every old person can become a magurang; one must prove that he is capable of discernment and is a leader who can be trusted and has the ability to settle disputes. In most cases, this role is inherited by the son of a recognized magurang, who receives early training in the art of settling disputes. In some cases, a person may become a magurang even though his father is not a magurang due to his recognized ability to settle disputes in the village (Rio, 2016).

Section 18 of the IPRA provides that "the ICCS/IPs living in contagious areas or communities where they form the predominant population but which are located in municipalities, provinces or cities where they do not constitute the majority of the population, may form or constitute a separate barangay in accordance with the Local Government Code on the creation of tribal barangays." The idea behind the concept of a "tribal barangay" is that the non-traditional barangay under the Local Government Code of 1991, and thus may not be responsive to the needs of the ICCs/IPs, as they have a different set of socio-political structure compared to that of that on non- ICCs/IPs (Gamosa, 2014).

Under Section 60, Chapter VIII of RA 8371, all lands certified to be ancestral domains shall be exempt from real property taxes, special levies, and other forms of exaction except such portion of the ancestral domains as are actually used for large-scale agriculture, commercial forest plantation and residential purposes or upon titling by private persons: Provided, That all exactions shall be used to facilitate the development and improvement of the ancestral domains. Section 61 of the same chapter states that 'prior to the establishment of an institutional surveying capacity whereby it can effectively fulfill its mandate, but in no case beyond three (3) years after its creation, the NCIP is hereby authorized to request the Department of Environment and Natural Resources (DENR) survey teams as well as other equally capable private survey teams, through a Memorandum of Agreement (MOA), to delineate ancestral domain perimeters. The DENR Secretary shall accommodate any such request within one (1) month of its issuance: Provided, That the Memorandum of Agreement shall stipulate, among others, a provision for technology transfer to the NCIP. Section 62 of the similar Article also encapsulates that 'In cases of conflicting interest, where there are adverse claims within 
the ancestral domains as delineated in the survey plan, and which cannot be resolved, the NCIP shall hear and decide, after notice to the proper parties, the disputes arising from the delineation of such ancestral domains: Provided, That if the dispute is between and/or among ICCs/IPs regarding the traditional boundaries of their respective ancestral domains, the customary process shall be followed. The NCIP shall promulgate the necessary rules and regulations to carry out its adjudicatory functions: Provided, further, That any decision, order, award, or ruling of the NCIP on any ancestral domain dispute or on any matter pertaining to the application, implementation, enforcement, and interpretation of this Act may be brought for Petition for Review to the Court of Appeals within fifteen (15) days from receipt of a copy thereof. Section 63 of it, also states that customary laws, traditions, and practices of the ICCS/IPs of the land where the conflict arises shall be applied first with respect to property rights, claims, and ownerships, hereditary succession, and settlement of land disputes. Any doubt or ambiguity in the application and interpretation of laws shall be resolved in favor of the ICCS/IPs. Based on Section 65 of Chapter IX of the Law, recognizes that when disputes involve ICCs/IPs, customary laws and practices shall be used to resolve the dispute. Section 67 of the same law, states that the Decisions of the NCIP shall be appealable to the Court of Appeals by way of a petition for review. Under section 69, the NCIP shall have the power and authority: a) to promulgate rules and regulations governing the hearing and disposition of cases filed before it as well as those pertaining to its internal functions and such rules and regulations as may be necessary to carry out the purposes of this Act; b) to administer oaths, summon the parties to a controversy, issue subpoenas requiring the attendance and testimony of witnesses or the production of such books, papers, contracts, records, agreements and other document of similar nature as may be material to a just determination of the matter under investigation or hearing conducted in pursuance of this Act; c) to hold any person in contempt, directly or indirectly, and impose appropriate penalties therefore; and d) to enjoin any or all acts involving or arising from any case pending before it which, if not restrained forthwith, may cause grave or irreparable damage to any of the parties to the case or seriously affect social or economic activity. Section 70 states that no inferior court of the Philippines shall have jurisdiction to issue any restraining order or writ of a preliminary injunction against the NCIP or any of its duly authorized or designated offices in any case, dispute or controversy arising from, necessary to, or interpretation of this Act and other pertinent laws relating to ICCS/IPs and ancestral domains.

There is no need for the creation of tribal barangays in the municipality of Calinog because each of the IC/IP communities already from a separate barangay, and on their own initiative, were able to affect orderly interfacing of the traditional community leadership structure with the non-traditional barangay leadership structure (Gamosa, 2014).

The only community in which there was haphazard or inordinate interfacing of the traditional community leadership structure with the non-traditional barangay leadership structure, are the two (2) barangays of Agcalaga and Cahigon, resulting in conflicts between the traditional and non-traditional leaderships of these barangays. Alibunan is an altogether different casa, already appearing to be a non-IC/IP barangay with a resettled IP population rather than an IC/IP community (Gamosa, 2014).

The likely candidate for such a political unit in Calinog is Sitio Marinas of Brgy. Tuyongan. However, considering that it constitutes a single sitio, it may not be able to meet the minimum requirements set by the Local Government Code of 1991 for the creation of a barangay (Gamosa, 2014).

The establishment of Indigenous Peoples Organization (IPO) is embodied in IPRA Law which guarantees the legal capacity to assist the ICC/IPS in ensuring their collective rights to their ancestral domains and to strengthen their political, economic, and social systems or institutions. This IPO must be registered and accepted as a legal representative as evidenced by a Certificate of Registration (CoR) and the Security and Exchange Commission. At present, the Calinog Indigenous People's Organization is an accredited non-stock, non-profit and non-sectarian in nature. The Organization aims to serve as a vehicle for the preservation of indigenous knowledge, culture, and tradition. This also serves as a venue to advocate and advance the cause of the indigenous people (SEC Order No. 116 s. 2012).

\subsection{The Establishment of School of Living Tradition in Calinog, Iloilo}

School of Living Tradition or Balay Turun-an is established in response to UNESCO's call for the preservation of cultural heritage by preserving it in a living form, ensuring its transmission to the next generations. This program primarily focuses on the transmission of indigenous skills and techniques to the young through culture specialists/masters. Essentially, this is just a portion of the rich cultural heritage of a certain Indigenous Peoples (IPs) community. Further, the program for the establishment of SLTs is anchored on the mandate of NCCA which are as follows: (1) conserve and promote the nation's historical and cultural heritage by encouraging and supporting the study, recognition, and preservation of endangered human cultural resources such as weavers, chanters, dancers and other craftsmen, as well as the conservation and development of such artistic, linguistic and occupational skills that are threatened with extinction; and (2) preserve and integrate traditional culture and its various creative expressions as a dynamic part of the national cultural mainstream by helping set up or encourage, monitor and subsidize companion systems at the regional, provincial and local levels, intended to develop traditional cultures such as arts/crafts centers, preferably in community 
settings apart from the usual museum settings, where exponents of living arts and crafts can practice and teach their art and enrich contemporary designs (Magos, n.d.).

The idea of putting up a school dedicated to the Panay Bukidnon or Sulod of Central Panay was conceived in 1992 when, as a struggling anthropologist, the author began her study of the Panay Bukidnon community and their oral literature - sugidanon (epic), ulawhay (long, chanted narrative), talda (repartee) and dilot (love song). This exercise, in turn, encouraged the Sulod to revive their cultural heritage (Magos, n.d.).

The School for Living Tradition (SLT) or Balay Turun-an is one where a living master/culture bearer or culture specialist teaches skills and techniques of doing a traditional art or craft. Its establishment is in consonance with UNESCO's call for the preservation of cultural heritage by preserving it in a living form, ensuring its transmission to the next generations. While there are various facets of cultural heritage that can be transmitted to the next generations, this program would like to specifically focus on the transmission of indigenous skills and techniques to the young. It aims to encourage culture specialists/masters to continue with their own work, develop and expand the frontiers of that work, and train younger people to take their place in the future (Austria, 2015). In these schools of a living tradition, children do not learn Science, Mathematics, English, Filipino, and Civix, but their epic chants. Their oral tradition, called 'sugidanon' which uses archaic language and is traditionally chanted while lying down in a hammock, is the longest in Asia. The chants tell stories about the legendary warriors of the tribe and their heroic exploits. Children also come to these schools to learn their dance called 'binanog', a courtship dance that mimics the flight of a mighty bird and that involves the use of scarves or a piece of cloth to catch or elude a partner. The children learn their tribe's lore, including 48 phases of the moon and names for constellations. They also learn to read sky patterns and predict the weather (Austria, 2015). The mode of teaching is usually non-formal, oral, and practical demonstrations. The site may be the house of the living master, a community social hall, or a center constructed for the purpose (NCCA, 2015). This is realized with the help of the NCCA, an agency under the Office of the 'President. The curriculum content of the school is based on the oral literature of the Sulod and framed within the Giya sa Pagtu-on (Guide for Learning) developed by the author (Magos, n.d.).

There is a minimum allowance for the students (for food, travel, materials, supplies, etc.). A modest honorarium for a local project coordinator (preferably the cluster head closest to the site of the learning center or a scholar from an academic institution in the area). Subsidize, through the SLT Grants Program, the operations of an SLT Project Staff composed of one consultant (to be recommended by the SCCTA) and one or two people in charge of day-to-day operations. Monthly honorarium for the Living Master / Teacher (for a period of one year, subject to renewal every year for a period of three years, after which the center is expected to be self-sustaining and income-generating). Locations may be at or near a civic center (ex. barangay, halls, municipal halls, city halls, local museums, or within the premises of an educational institution). The students are not necessarily from the ethnolinguistic community of the living master. Students may be anybody recommended by the cultural workers, officials, and residents of the barangay, municipality, province, or SCCTA.

In Calinog particularly Brgy. Agcalaga, the Balay Turun-an was conceived as a pilot project with only fifteen selected students or even less. The sessions are held on a Saturday because during weekdays the children help their parents on the farm and in domestic chores. Due to the increasing number of enrollees, the budgetary becomes limited, and cannot afford to have several classes (Magos, n.d.). The criteria for selecting children enrollees are; interest of both children and parents, health, age, and commitment. A contract is signed after a child is interviewed by the parent/guardian. At the outset, they are informed of the expectations that go with the enrolment (Magos, n.d).

\section{Methodology}

This study employed an ethnographic research design. Ethnography is the study of social interactions, behaviors, and perceptions that occur within groups, teams, organizations, and communities. It arises from the discipline of social and cultural anthropology where an ethnographer is required to spend a significant amount of time in the field (Creswell, 2014; Wolcott, 2010). This design is appropriate inasmuch as it requires the researchers to get immersed to study the social and cultural contexts of the Panay Bukidnon-Halawodnon in barangay Agcalaga, Calinog, Iloilo, Philippines.

This ethnographic research design employed key informant interviews, fieldwork, ancillary participants, non-participant observation, and document review to ensure the validity and accuracy of the gathered data. Chosen through purposive sampling, the key informants of the study were the elders of the community or "magurangs", chieftain and culture while the barangay captain and cluster head of Panay Bukidnon-Halawodnon served as ancillary informants. All members of the Council of Elders were invited to Focus Group Discussion (FGD). However, only 9 out of 11 responded and attended the undertaking. Moreover, non-participant observations and document reviews were utilized and analyzed to supplement the result of this study.

The researchers utilized researcher-made interview/FGD protocols which were both foreshadowed beforehand to the noninformants who exhibited similar conditions with the real informants. The interview, FGD, and observation protocols were crafted 
on the basis of a sufficient literature review of the researchers. Data triangulation, member checking, and ground truths were conducted to ensure the validity of responses and data. Data saturation was also observed for the reliability of the study.

A letter of permission from the Office of the National Commission for Indigenous Peoples (NCIP) Regional Office VI/VII was secured. Upon approval, a short conference with the officials and Council of Elders was set prior to the visit to the research locale. Letters of the same nature were also sent to the Municipal Police Office, Military and Brgy. Captain and Chairman of Panay BukidnonHalawodnon assigned in the area. Before the conduct of fieldwork, the researchers commissioned a "gatekeeper" to penetrate the place and establish rapport, mutual trust, and respect for each other. The informants were encouraged to sign in the informed consent forms. Video and audio recordings and photographs were taken to support the conduct of such methods with the consent of the participants.

The analyses of interviews, observation, field notes transcripts began with the researchers' listening to the participants' responses which were collaborated with audio-video recordings and photographs. The raw data were transcribed in toto based on the dialect used by the participants using Microsoft Word Program. Thereafter, the researchers made an outline for the information they had. Next, they organized the data around a narrative sequence using the NVivo 12 Plus software. Codes, categories, and themes were developed, respectively.

\section{Results and Discussion}

Results revealed that barangay Agcalaga, Calinog, Iloilo, Philippines can still be considered as indigenous despite their having been assimilated into the larger mainstream society. This is because most of the Panay Bukidnon-Halawodnon in the said place continue to uphold their culture as evident in their ways and other supporting evidence, especially the efforts undertaken by their Council of Elders.

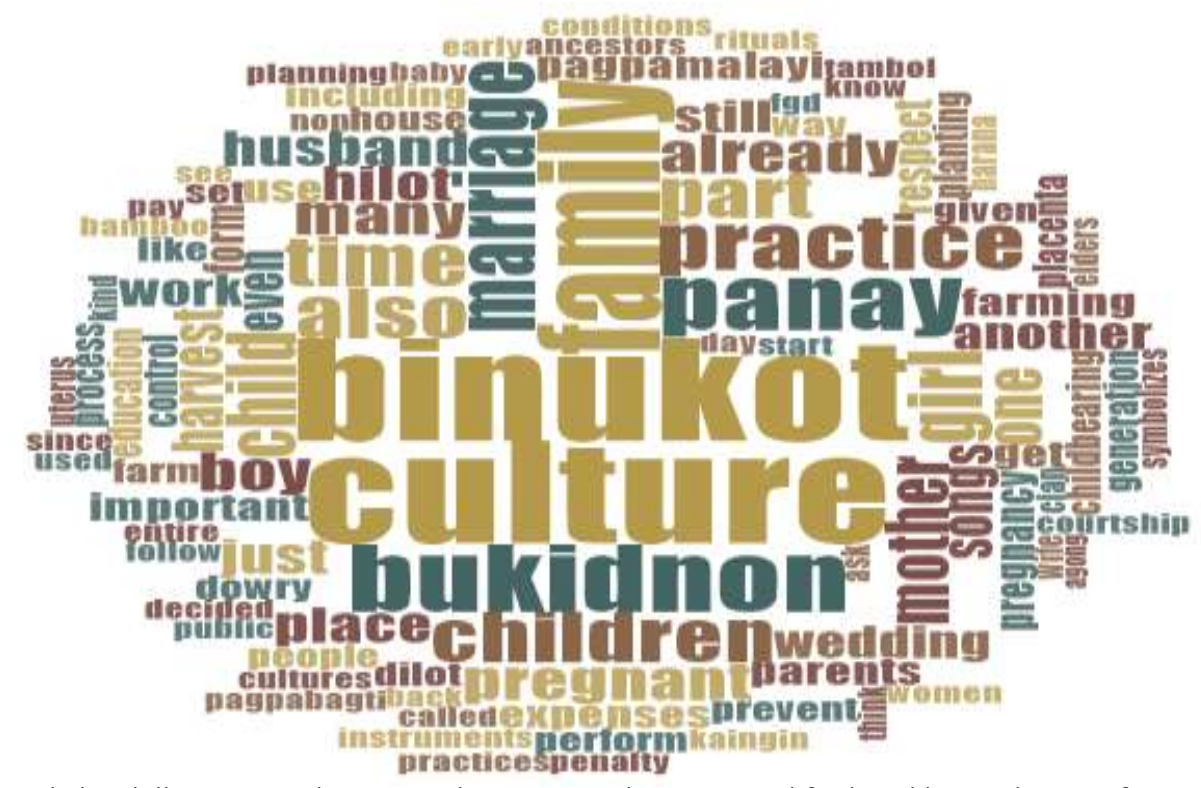

Figure 1. Word cloud illustrating the strengthening, weakening, modified and lost cultures of Panay Bukidnon-Halawodnon

Figure 1 shows that Binukot and Family came out as the most prevalent issues with respect to the strengthening and weakening cultures of the IPs in Agcalaga. The Panay Bukidnon-Halawodnons recognize the vital role of the Family in reinvigorating and salvaging their weakening or dying culture. They believe that the teaching of culture must be cascaded to the family in order to yield strong and positive outcomes. On the other hand, the culture of Binukot in the place is already lost but remains in the minds of the IPs. They know how Binukot is made but it does no longer exist due to conflicting state laws.

The cultural preservation of Panay Bukidnon-Halawodnon yields four (4) themes: (a) Strengthening, (b) Weakening, (c) Modified, and (d) Lost Cultures.

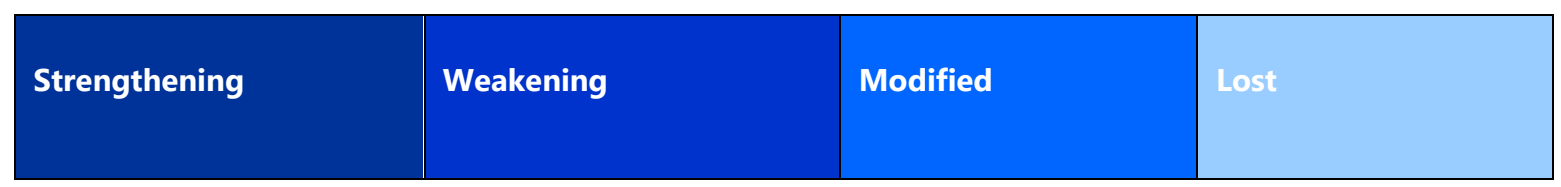




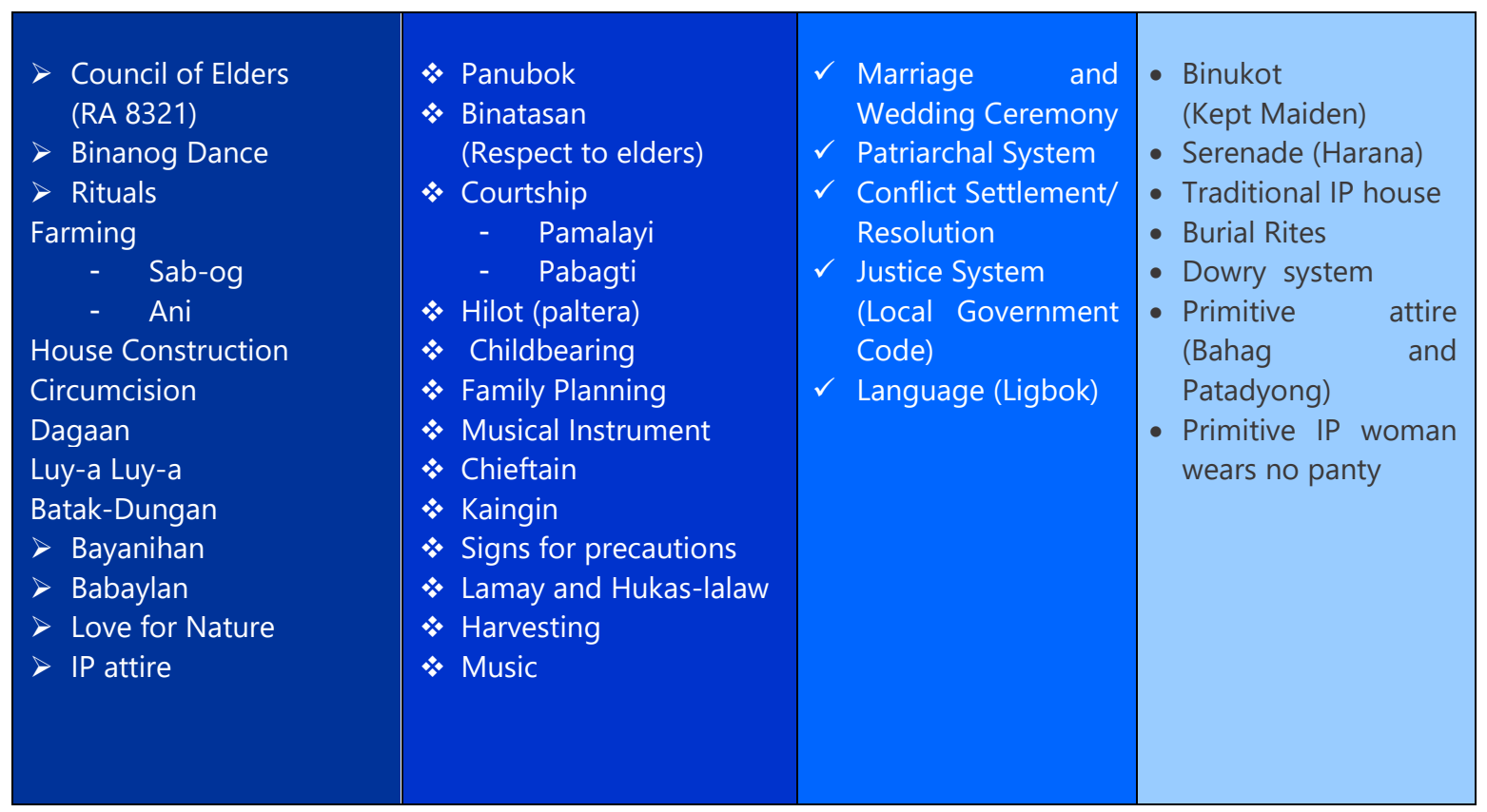

Table 1. The strengthening, weakening, modified and lost cultures of Panay Bukidnon-Halawodnons

\subsection{The Strengthening Cultures}

Adulfo says: "The council of elders is trying to preserve and teach our cultures to the younger generations, the reason why they are already proud now to declare that they are members of the IP community". Alfonso emphasizes: "The people in the community will just point their hands to the elders whom they want to lead the community. These must be persons with integrity and respected by the people. There is no election to choose the head or the chairman, but it was always based on attitude and respect of the people. If the people will not respect you, then you have no chance to be the head of the community".

According to Adulfo, "Binanog" comes from the word 'banog' which means hook or 'dapay' (a kind of bird) which is endemic in Panay. This is where the old people of Panay Bukidnon got their idea of dances. The stepping and hand movements mimic 'dapay'. They can really see these movements when they see the bird's way of courting. This traditional dance is very popular in Manila, Mindanao, and the Visayas. Most of the natives are truly skillful in performing 'binanog' especially those children who are studying in the SLT." Ester further shared: "There is more than just dancing 'binanog'. The beat of 'tambol' and 'agong' should be synchronous to the sound of the feet of the dancers '(padag-padag)'. That is why 'salog' is important in dancing 'binanog'. This culture must not only be internalized and lived out by the elders but also the children".

The life of the Panay Bukidnon-Halawodnon is brought with many rituals. These rituals are always integrated and are part of the daily routine of the natives. Adulfo said: "They believe that when the tiwtiw (bird) sounds, the ceremony of circumcision will not push through because it was their belief that the circumcision will be bloody. Another important ritual is during the planting and harvest seasons. Different ceremonies are being done during planting. A day before the 'sab-og' (planting), they will offer a dozen eggs, lemongrass, leaves of bugnay and observe that when no leaves fall, it is not yet time to sab-og because the plants will be prone to insect attack". He added, "During harvest time we do not allow anybody on harvesting the rice field to go around and move from one place to another to prevent the 'magtigawhang' or diminishing the quantity of harvest." The same ritual is observed when they construct houses or buildings. Adulfo added: "We first measure the size of the house we want to construct and use 'bulo' (a kind of bamboo) as a guard to the desired area and try to observe our dreams. If we dream nothing, the area is favorable but if we dream something bad, we should repeat the ritual and change the area. We often use 4 bulos in forming a square; lying on the square which means that area is being asked to be constructed. Through dreams, we can ascertain whether that area is favorable or not." Erning said: "We still practice 'daga' or 'daga-an' because we believe that before we enter a certain place, we should ask permission from the unseen creatures. It is usually performed by the well-respected 'babaylan' in the community."

Another way of looking into the culture of the Panay Bukidnon-Halawodnon is how they love and care within themselves the desire to uplift and continue the living traditions of their ancestors. To Erning: "Every family should teach and hone its children about culture, more specifically attitude because they believe that if the teaching of culture is still practiced in every household, their culture will not fade. The burning desires from their hearts to continue their culture cannot be measured or gauged by any instrument."

\subsection{The Weakening Culture}


The' tubok' (cloth-making design) gives the true identity of the Panay Bukidnon but, sad to say only a few know how to make such perfectly. According to Adulfo, "I also observed that we lack skillful persons in 'panubok', the designers of the fabric. Therefore, I see the need to continue training the children to make 'panubok' because as I observed there are only 3 persons in Agcalaga who are skillful in doing such. Many natives are not interested anymore to practice such a culture, the reason why it weakens gradually. It is their way of weaving or making designs in their clothes. Conventionally, when the cloth is white, the 'panubok' is made of red and vis a vis."

The early Panay Bukidnon believe that respect is accorded not only to one's family but also to others. It is the culture of selfdiscipline, respect, and admission of one's fault. Erning shares: "There are cases where an IP does not pay respect to others and cannot afford to say 'sorry' if he/she does wrong." This is actually a clear contradiction of their culture which capitalizes on proper and right discipline among children. Nevertheless, the good thing about their culture is somehow alive in the veins of the 'malams' (elders). Jorge shares: "During the time of our forefathers, strict discipline was imposed among children. The children can easily grasp the meaning of the gesture and abide when their parents stare at them. Unluckily, only the elders have the determination to preserve their tradition but children have different ways of perceiving the kind of respect and discipline the way it was before." They can truly say that the culture of discipline and respect is weakening among the Panay Bukidnon-Halawodnon. Jorge adds: "The reason why we still encourage our children and the younger generations to continue schooling in the SLT even though it is already in Datagan".

Courtship in the Panay Bukidnon-Halawodnon is considered a long-held tradition before marriage. They practice courtship in the form of offering songs or serenades (harana/dilot). According to Adulfo: "The dilot is part of the culture of the courtship of the Panay Bulidnon-Halawodnon where the man courts and informs the lady about his coming through songs or serenades. On the other hand, Adulfo adds: "Talda" follows where the man and the lady have conversations in the form of songs". Erning further declares: "There is a big difference in the cultural practices before and today. Dilot is the old song of the early Panay Bukidnon. But it is rarely heard now. It's good that I am still here and capable of performing such. We rarely use or recite our songs due to limited activities where we can show off our culture. Nevertheless, I can still sing 'dilot' if someone asks me to perform".

The family planning program of the government also helps weaken the culture of the Panay Bukidnon-Halawodnon. As part of their culture, having many children in the family is a blessing and serves as family treasures. Jorge adds: "The more children we have, the merrier. When we start the kaingin process, all the male children work on it and it will be easy for the family to finish the work because more hands are doing".

Further, the title "Chieftain" is no longer used today; instead, is now "Chairman of the Council". Adulfo says: "We are having trouble right now since NCIP ceases the title of chieftain. In fact, I try to ask why they have to do this since they are not IPs in the very first place. We are IPs and we know what we are doing. We should have a leader to recognize. "Technically speaking, there is term as chieftain as far as NCIP Region VI/VII is concerned. It is one of our problems. They should be there to support us not to suppress".

The kaingin system is another weakening culture and practice since cutting of trees is already prohibited by the government, specifically the DENR. George says: "We just utilize some areas for kaingin where no trees are needed and can hamper farming or craft. We still emphasize the importance of environmental preservation in order to maintain the source of water or 'tuburan' and, as you can see here the water is overflowing".

Moreover, there are beliefs that the Panay Bukidnon-Halawodnon seldom practiced and followed by the younger generations. Their way of giving precautions on some uncontrolled happenings or danger is through believing in signs. According to Erning, "When a man is about to go to his duty but suddenly sneezes, or when he hears an unusual sound of birds and or his child cries unusually, the man must not pursue his destination because it is believed that something can happen to him or it is a sign of bad omen". Jeoge also admits: "When it is cloudy above the mountain in the morning, it is a sign that the weather is not fine. But when no clouds can be found early in the morning, it's an indication of good weather for the whole day".

\subsection{The Modified Culture}

The Panay Bukidnon-Halawodnon does not practice the marriage contract signing during the wedding ceremony. The words of the Chieftain and the elders who serve as witnesses are already binding. Adulfo asserts: "For us, we are hesitant to embrace the present practice of the people because it will indicate the extinction of our culture. We prefer to revive the kind of marriage culture than to embrace the culture of the mainstream. We are not against the marriage system of today but we would like that the conditions attached to both parties will be fulfilled. What is the saddest part today is that the ladies get married because they get pregnant before marriage." Adulfo adds: "Marriage without consent of the elders is prohibited in our culture. But now, anybody can sign a marriage contract as long as one is of legal age even without the consent of the parent". 
In addition, the "Ligbok" as the official language of Panay Bukidnon is not mixed with other languages. According to Erning: "For example, Had'e Kaman, means where are you going? There are times when we speak in mixed - with karay-a and ligbok but oftentimes we do not. We often speak with raised "E". It cannot be taken from them when we speak, we utter "e", "eyy". Hearing people saying with "ey", that's Panay Bukidnon- Halawodnon identity. The language almost fades in several decades because people get discriminated against if they speak it. We sometimes avoid using that language to avoid being tagged as 'tagabukid gid, mga bukidnon!'

\subsection{The Lost Culture}

"Binukot" is unique in Panay Bukidnon-Halawodnon; it attracts the eyes and interests of some researchers, people, historians, and the like around the country. Many people are interested in the culture and life of the "Binukot". When the girl is chosen to be the Binukot, she is considered the most privileged one. However, Adulfo says: "There is no more existing 'Binukot' today. The last 'binukot' who died was not a resident of barangay Agcalaga; she was from Tapa, Capiz. There is no recorded binukot in Agcalaga, only in Garangan and other places". There are some government laws questioning the culture of 'binukot'. For example, Gender and Development (GAD). People nowadays are aware of their rights. They can accuse the parents if they maintain 'binukot' and deprive her of worldly life."

\subsection{Reasons that Help or Hinder the Propagation of their Cultures}

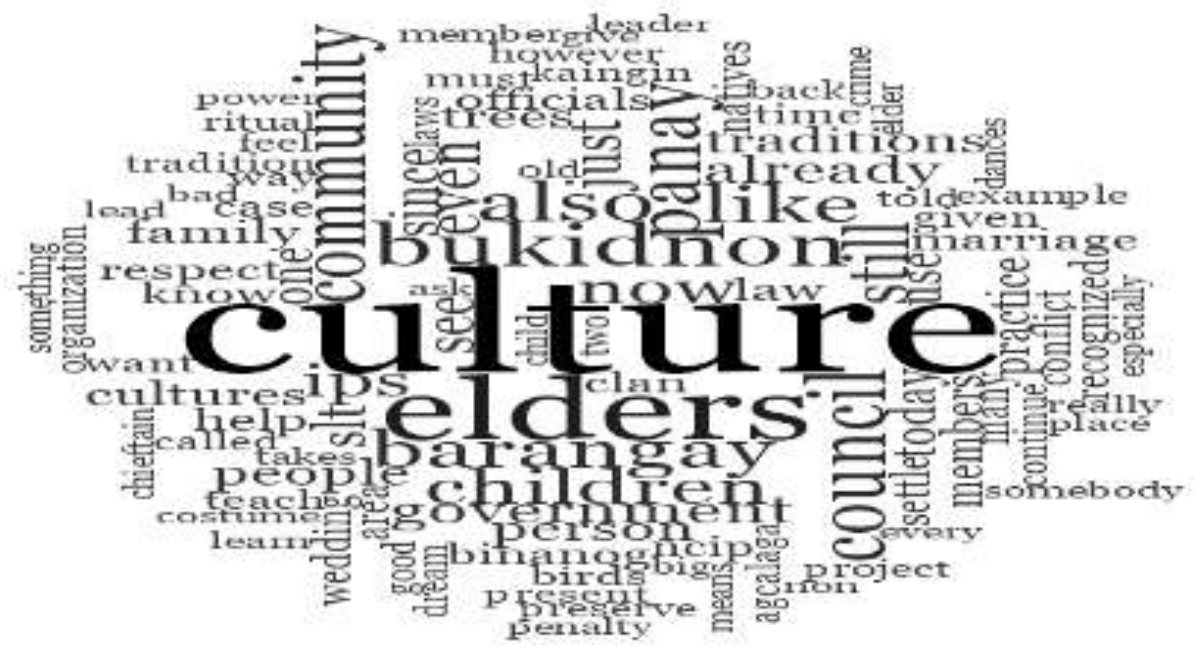

Figure 2. Word cloud on the reasons that help or hinder the propagation of their cultures.

As shown in Figure 2, Culture came out as the most frequently used word among Panay Bukidnon-Halawodnons in barangay Agcalaga. This could mean that the culture of Agcalaga is now in its midway because as the people keep on holding on to their culture, they are at the same time embracing the emergence of unprecedented events or institutions in their community. Henceforth, this event is somewhat disturbing since the culture of IPs in the said place is not as stable as it was before. This somehow contributes to the deterioration of some cultures of the said cultural community. Moreover, the composition of the Council of Elders is indeed crucial and critical in defining their cultural community. Being esteemed representatives of the clan, the elders are responsible for and accountable to the welfare of their clan members and the preservation of their culture amidst the influx of modernization and globalization.

Based on a systematic analysis of data, the following are themes on the primary reasons behind the propagation of the culture of Panay Bukidnon-Halawodnons: RA 8371 or IPRA Law; The National Commission for Indigenous Peoples (NCIP); The Help Extended by the National Commission for Culture and Arts (NCCA); Privileges and Scholarships for the IPs; The Role of the Council of Elders; The Role of the School of the Living Traditions (SLT); Through Representation in the National Level; Certificate of Ancestral Domain Title (CADT); Proud of their Culture; Marriage, Birth and Death Certificate - Pilot Administration (Calinog); and The Indigenous Knowledge System and Practices (IKSP).

\subsubsection{RA 8371 or IPRA Law}

The Panay Bukidnon-Halawodnon of barangay Agcalaga is one of the IP communities in the central part of Panay covered by the IPRA law and enjoying some rights and privileges of the said law. Through this law, they are given the chance to be recognized by the community and have the privilege of enjoying their lives to the fullest. Adulfo said: "We are thankful that the government is helping us to revive our fading culture. We feel that our rights are now recognized and given importance by the government". 


\subsubsection{The Role of the Council of Elders}

The Council of Elders has a big part in the preservation and recognition of the IP community because through the Council of Elders, they were recognized by the people. Jorge says: "We have observed that some traditions and cultures are gradually coming back. We have tried to preserve the traditions we have especially at home. In fact, we teach our younger generations the kind of respect they should give to their parents, elders and even to all the people regardless whether IPs or non-IPs". "For almost two decades, the Panay Bukidnon-Halawodnon community has lost its identity but through the organization of the Council of Elders, the Panay Bukidnon-Halawodnon is back, Adulfo adds.

\subsubsection{The Role of the School of the Living Traditions (SLT)}

According to Ester, "It is only through SLT that we realized the need to teach and preserve our culture. It has become an eye-opener to us that we learn a lot of these from the knowledgeable IPs". As of now, the SLT in Agcalaga is non-operational but they still continue to send their children on Saturdays and Sundays to continue learning the cultures. Jorge added: "We still continue to preserve these traditions today in barangay Agcalaga. We still encourage our children and the younger generations to continue learning our handed traditions." Adulfo points out, "SLT is very important to us because it teaches the natives the culture of 'panubok', history, dances, 'binanog' and others. When we see our culture in our children, it means that our culture is living".

\subsubsection{Inconsistencies in the Laws of the Land (Constitution, Statutes, Republic Acts)}

Adulfo adds: "The law is sometimes selective. It is not fair to all especially to the IP communities". "Some major reasons for the weakening of our culture are the conflicting provisions in some laws or the Republic Acts. We call them oppressive because our newborn children will not be allowed to be registered in the civil registrar when not born in hospitals or through registered midwives or in health centers. We were prohibited to seek help from the 'hilot'. Different government agencies have also introduced policies that hinder some cultures to be fully revived".

\subsection{Suggestions of IPS to address their Cultural Struggles}

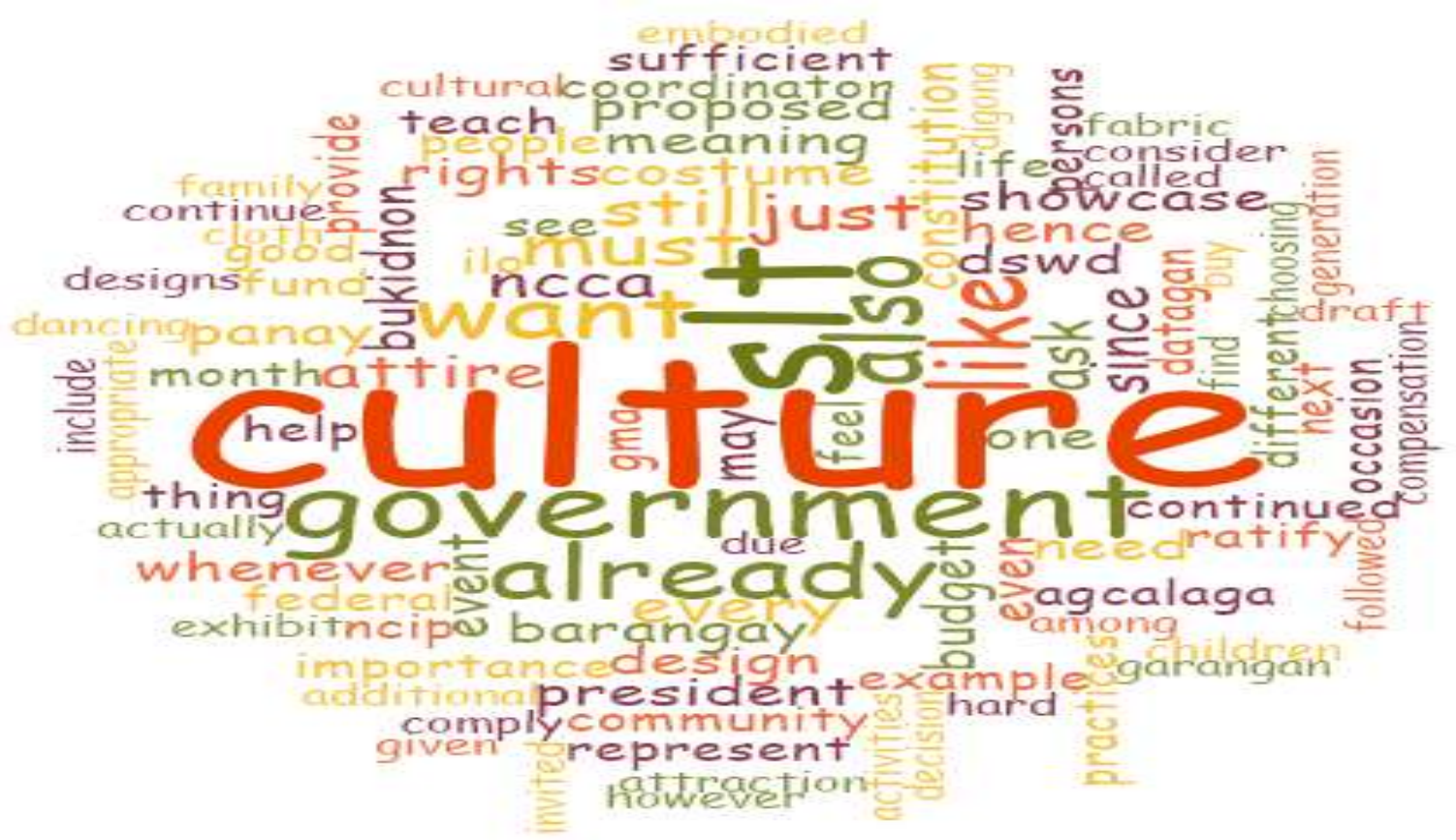

Figure 3. Word Cloud on the suggestions of IPs to address their cultural struggles.

As shown in Figure 3, Culture came out as the most frequently used word among Panay Bukidnon-Halawodnon in barangay Agcalaga. This means that IPs in Agcalaga acknowledge that their culture is now at risk, and therefore must be given much emphasis and importance in order to preserve their culture. We observe that governmental help is vital in the realization of this cause. The natives are asking for the revival of SLT in the place for they consider the latter as an instrument in maintaining a strong, sturdy, and solid culture.

\subsubsection{Nature of Panay Bukidnon-Halawodnon Costume}


As shown in <Image 5 Here>, the Panay Bukidnon-Halawodnon costume is considered sacred. Thus, it must only be worn during special occasions and not on ordinary days. Each design denotes meaning and this meaning is not usually divulged to anyone. For instance, during the Hirinugyaw-Suguidanonay, Adulfo shares, "Since the dances showcased during that event is a Panay Bukidnon, the judges should also be IP, not anyone else. For example, is the Ulitaw and Lin-ay. We are not against the participants but we run after how it is being executed and worn. They should only focus on culture and if they want additional attraction, they should not use the attire of Panay Bukidnon. They should not modify the occasion or exhibition like the wearing of tupis."

\subsubsection{Revival of the School of Living Traditions or Balay Turun-an}

As shown in <Image 6 Here>, the School of Living Tradition or Balay Turun-an is considered as the $2^{\text {nd }}$ life of the Panay BukidnonHalawodnon. It serves as an agent in propagating their culture and has become the center point of all cultural occasions in the barangay. According to Zenia: "SLT in Agcalaga becomes the center point of some SLTs and other people on certain occasions. They rent costumes for the event like Hirinugyaw-Sugidanonay. Essentially, the SLT here is open but holds no classes due to the absence of funds." Jimmy adds, "For me SLT is life. It is like love is life, when we do not have love, we are already dead. We consider SLT as our $2^{\text {nd }}$ life for our culture to be recognized. If we have land, we should have culture. We can never be called IP if we do not have culture." Norio also shares, "As a matter of fact, our culture might collapse in the next generation without NCCA". Hence, there is a need to revive, restore, and re-established the SLT in Agcalaga. Because it is fully operational, the land has a deed of donation and should be renovated but the salog should be retained. Zenia adds, "The beat of the 'tambol' and 'agong' should be synchronous to the sound of the feet of the dancers (padag-padag). The 'salog' is very important in dancing 'binanog'." On the other hand, Delfin shares, "Unlike the ordinary SLT that takes 3-6 months, the Enhanced SLT in Datagan is sustainable and cohesive. It has one (1) admin known as the local coordinating team to implement, liquidate funds and do the paperwork." The teaching of culture must be holistic and must include all cultural arts, as in Datagan. Delfin further tells "This SLT in Datagan has taught 5 art forms. It is a model program since they provide only a framework or guidelines; the implementation is usually customized. Not all cultural communities have the same condition, that is why the implementation varies." Adulfo conforms and adds, "The culture masters should be expert or knowledgeable enough and should justly and fairly be paid. Additional machinery can enhance teaching, too. Once revived, SLT must be under the supervision of the Council of Elders and Barangay Council to ensure its proper implementation. Further, there should be a strong link with the government officials and other relevant agencies, like the NCCA."

\subsubsection{Representativeness of Panay Bukidnon-Halawodnon in Various Events}

As shown in <Image 7 Here>, proper representation of Panay Bukidnon-Halawodnon can be achieved by: (a) having IP representatives in various government agencies or sectors, like youths and Senior Citizens; (b) pursuing the Indigenous Peoples Municipal Representative (IPMR); (c) Fair Representation in Garangan-Masaroy-Agcalaga Community; (d) the president of GMA community should be a native IP, and (e) sharing of culture with other culture masters whenever occasion permits.

According to Jimmy, "Under IPRA law, IPMR is required to represent the IP in the Sanguniang Bayan and SanguniangPanlalawigan or LGU. Last November 2018, a resolution was passed in creating this group but was not realized due to the incoming elections. Whoever is the first priority assumes the position and anytime it may be withdrawn due to people's distrust. The IP representative is monitored by the NCIP. Some areas like Aklan have their IPMR." Zenia further said: "IPs in GMA have their own organization. The president was told to choose a representative in any cultural gathering. All communications are directed to the president except when somebody invites a specific person to attend the said undertaking. The president should come from the IP itself without any obligation to fully harness his potentials thru attendance in gatherings and affairs."

\subsubsection{Legal Remedy}

As shown in <Image 8 Here>, the participants laid down the possible legal interventions to salvage their own culture.

Jimmy shares, "When I attended a seminar in Iloilo, I saw the draft of the proposed federal government; among the 48 drafts, IP law was not included. I recommend including IP law in the draft of federalism. Moreover, I would like to ask the government to recognize the 4 rights of IP embodied in IPRA and ratify the ILO 169 which requires Congress to do it. The Philippines is the sole IP country that does not ratify this. We need to ratify this because even if IPRA is rescinded, IP rights are still protected since it has already its power under our Constitution." Likewise, the NCIP should be retained under the Office of the President, not under the DSWD. Adulfo says, "The NCIP should remain under the Office of the President. There is a proposal that the NCIP will be under the DSWD. It is only the NCIP that helps us and if it will be under the DSWD, I'm sure it would be hard for the NCIP to conduct programs and even allot its budget. On the other hand, Panay Bukidnon is one of the few cultural communities that does not have a recognized chieftain. Some parts of Luzon and even Mindanao have recognized chieftain. For us, we need to have a legitimate chieftain to avoid conflict and to have formal representation in cultural gatherings."

\subsubsection{IPs Part in Cultivating their Own Culture}

As shown in <Image 8 Here>, the parents of each family have a greater obligation to nurture and teach their children about their culture. Even the simplest way of respecting others as part of their tradition can help a lot in influencing other people. This role 
cannot be fully taken by the elders since they also have several roles to play in the community and their respective families. Lozada shares: "I consider every home as a cornerstone of culture. Hence, the family should teach and hone children about their culture more specifically their attitude. I believe that if the teaching of culture is still practiced in every household, culture will not fade swiftly." Moreover, the Council of Elders should take an initiative with the support of the government to plan out programs or projects where IPs can convene and bond with one another and showcase and teach their culture. Lastly, part of the SLT fund should be appropriated to livelihood projects to ensure their sustenance. Welma shares: "Most SLT fail because of misappropriation and an enterprise of the family. We should discourage the culture of asking. Remember not everything will be provided by the government. It's up to the people how to sustain their SLT once it is funded. They should not only depend on the funds given, rather there should be other work. SLT can also be a venue for livelihood which can help in the mass production of native products."

\section{Conclusion}

The current cultural practices among Panay Bukidnon-Halawodnon were deeply accounted for by the employed methodology. It specifically uncovered different facets of the cultural ways of this Indigenous group. It was concluded that the said cultural community in Barangay Agcalaga is continuously progressing in terms of economic, social, and cultural contexts. This is due to the emergence of social institutions in the barangay, particularly the JRMP II. There is Indigenous Organization in barangay Agcalaga, Calinog, lloilo; however it is not accredited by the NCCA and NCIP. The culture of Panay Bukidnon-Halawodnon in Agcalaga is loosely fading due to the emergence of today's societies. Nevertheless, there are still cultural practices that are invigorating yet need much support from the government and the people. School of Living Traditions or SLT in Agcalaga needs attention in order to ameliorate the dying and revive the lost cultural practices of the natives. It is further concluded that the Philippine government provides incentives to performing elders and/or IP members and provides a venue for regular assembly or gathering among Ips to showcase their culture and exhibit their native products. Thus, the ratification of the Congress to Indigenous and Tribal Peoples Convention No. 169 or Convention 169 will help protect and preserve the cultures of the Indigenous Peoples not only in Calinog, Iloilo but also in the entire country.

Funding: This research received no external funding. All the expenses were shouldered by the researchers, including the permits and other documents secured from the National Commission for Indigenous Peoples (NCIP) and the Council of Elders.

Acknowledgments: The authors would like to express their gratitude to the Council of Elders of Panay Bukidnon-Halawodnon and other resource persons who voluntarily participated and approved this research to be published in an educational journal.

Conflicts of Interest: The authors declare no conflict of interest.

\section{References}

[1] Asong, R. H. \& Seraspe, E (2002). Reproduction and fertility management practices of the PanayBukidnon. University Center for Women's Studies, University of the Philippines in the Visayas, lloilo City, Philippines

[2] Austria, K. (2015). Panay bukidnon's last 'binukot'. Retrieved from https://www.pressreader.com/philippines/philippine-dailyinquirer/20150929/281509339995216

[3] Basco, N. (2008). Panay-Bukidnon celebrates Indigenous People's Day. Retrieved from https://news.abscbn.com/nation/regions/11/01/08/panay-bukidnon-celebrates-indigenous-peoples-day

[4] Creswell, J. W. (2014). Research design: Qualitative, quantitative, and mixed methods approach. 4th ed. Thousand Oaks, California: SAGE Publications

[5] Ferolino, W. P. M., Fernandez, J. G. S., Laspinas, R. M. G., Lau, A. J. G. \&Pero, R. F. P. (2010). Food culture of the indigenous people of lambunao, Iloilo. Unpublished Thesis, West Visayas State University, Iloilo City, Philippines

[6] Gamosa, S. G. (2014). The socio-political organization of the bukidnon (halawudnon-bukidnon) indigenous cultural/Indigenous Peoples (IC/IP) communities of calinog, Iloilo. National Commission on Indigenous Peoples, Regional Office 6, lloilo City

[7] Gowey, D. (2014). Contextualizing the sugidanon: Providing a framework for inquiry. National Conference on the Sugidanon (Epics of Panay). The University of the Philippines-Visayas, Iloilo City, Philippines. December 4 th- $5^{\text {th }}$

[8] Magos, A. P. (n.d.). Balayturun-an: An experience in implementing indigenous education in central panay. Retrieved from http://116.50.242.171/PSSC/index.php/agt01/article/viewFile/1788/1641

[9] Muyco, M. C. (2016) Sibod: Ideology and expressivity in binanog dance, music, and folklore of Panay Bukidnon. Ateneo de Manila University Press, Quezon City. ISBN 978-971-550-742-4

[10] National Commission on Indigenous Peoples (2013). Census of Brgy. Garangan, Masaroy and Agcalaga, Calinog, Iloilo

[11] National Commission on Indigenous Peoples, Regional Office 6, Iloilo City

[12] NCIP Administrative Order No. 2. s. 2012 (The General Guidelines on the Confirmation of Indigenous Political Structures and the Registration of Indigenous Peoples' Organization)

[13] NCIP Administrative Order No. 3 series of 2012. The revised guidelines on free and prior informed consent (fpic) and related processes of 2012

[14] NCIP Administrative Order No. 1 Series of 2012. The Indigenous Knowledge Systems and Practices (IKSPs) and Customary Laws (CLs) Research and Documentation Guidelines of 2012

[15] Panay bukidnon culture (2017). Retrieved from https://www.haliya.co/stories/2017/6/23/panay-bukidnon-culture 
[16] Resolution No. 2012-061 (Adopting Committee Report No. 2012-03 of the Committee on Accreditation and Approving Its Recommendation In Toto)

[17] Resolution No. 2013-04 (A Resolution Informing the Regional Director Alfonso B. Catolin, CESO III, National Commission on Indigenous Peoples (NCIP) Office, Region VI the Existence of Calinog Indigenous Peoples Organization (CIPO) Incorporated)

[18] Resolution No. 3 - 2013 (KomunidadkamgaBukidnonka Barangay Cahigon)

[19] Resolution of Barangay Garangan, Masaroy and Agcalaga (GMA)

[20] Republic Act No. 8371known as the Indigenous Peoples' Rights Act

[21] Rio (2016). TUBIGANAY: CONFLICT RESOLUTION AMONGST INDIGENOUS CULTURAL COMMUNITIES IN CENTRAL PANAY MOUNTAINS (n.d). http://clgips.cpu.edu.ph/tubiganay-conflict-resolution-amongst-indigenous-cultural-communities-in-central-panay-mountains/

[22] Security and Exchange Commission Office Order No. 116 s. 2012 (Certificate of Incorporation of Calinog Indigenous Peoples Organization (CIPO), Inc.)

[23] School for living tradition - a different school on culture (2005). Retrieved from http://archives. pia.gov.ph/?m=12\&sec=reader\&rp $=2 \& \mathrm{fi}=\mathrm{p} 050121 . \mathrm{htm} \& \mathrm{no}=12 \&$ date $=01 / 21 / 2005$

[24] Talledo, T. T. (2004). Construction of identity in CentralPanay: A critical examination of the ethnographic subject in the works of Jocano and Magos. Volume 40 Number I

[25] Wolcott, H. F. (2010). Ethnography lessons: A primer. Walnut Creek, CA: Left Coast Press. 